\title{
Effects of nutrition on digestion efficiency and gaseous emissions from slurry in growing pigs: III. Influence of varying the dietary level of calcium soap of palm fatty acids distillate with or without orange pulp supplementation
}

\author{
W. Antezana, S. Calvet, A. Beccaccia, P. Ferrer, C. De Blas, \\ P. García-Rebollar, A. Cerisuelo
}

Keywords:

Ammonia emission

Calcium soap of palm fatty acids

Digestion efficiency

Growing pigs

Methane emission

Orange pulp

Slurry

\section{A B S T R A C T}

The aim of this study was to establish the relationships between faecal fat concentration and gaseous emissions from pig slurry. Five diets were designed to meet essential nutrient requirements: a control and four experimental feeds including two levels ( 35 or $70 \mathrm{~g} / \mathrm{kg}$ ) of calcium soap fatty acids distillate (CSP) and 0 or $200 \mathrm{~g} / \mathrm{kg}$ of orange pulp (OP) combined in a $2 \times 2$ factorial structure. Thirty growing pigs (six per treatment) were used to measure dry matter (DM) and $\mathrm{N}$ balance, coefficients of total tract apparent digestibility (CTTAD) of nutrients, faecal and urine composition and potential emissions of ammonia $\left(\mathrm{NH}_{3}\right)$ and methane $\left(\mathrm{CH}_{4}\right)$. Increasing dietary CSP level decreased DM, ether extract (EE) and crude protein (CP) CTTAD (by 4.0, 11.1 and 3.5\%, respectively, $P<0.05$ ), but did not influence those of fibrous constituents. It also led to a decrease (from 475 to $412 \mathrm{~g} / \mathrm{kg} \mathrm{DM}, P<0.001$ ) of faecal concentration of neutral detergent fibre (aNDFom) and to an increment (from 138 to $204 \mathrm{~g} / \mathrm{kg}, P<0.001$ ) of EE in faecal DM that was related to greater $\mathrm{CH}_{4}$ emissions, both per gram of organic matter $(P=0.021)$ or on a daily basis $(P<0.001)$. Level of CSP did not affect $\mathrm{N}$ content in faeces or urine, but increased daily DM $(P<0.001)$, and $\mathrm{N}(P=0.031)$ faecal excretion with no effect on urine $\mathrm{N}$ excretion. This resulted in lesser $(P=0.036) \mathrm{NH}_{3}$ potential emission per kg of slurry. Addition of OP decreased CTTAD of EE (by 7.9\%, $P=0.044$ ), but increased $(P<0.05)$ that of all the fibrous fractions. As a consequence, faecal EE content increased (from 165 to $177 \mathrm{~g} / \mathrm{kg} \mathrm{DM} ; P=0.012$ ), and aNDFom decreased greatly (from 483 to $404 \mathrm{~g} / \mathrm{kg} \mathrm{DM}, P<0.001$ ), which in all resulted in a lack of effect of OP on $\mathrm{CH}_{4}$ potential emission. Inclusion of OP in the diet also led to a significant decrease of CP CTTAD (by $6.85 \%, P<0.001$ ), and to an increase of faecal CP concentration (from 174 to $226 \mathrm{~g} / \mathrm{kg} \mathrm{DM}$, 
$P<0.001$ ), with no significant influence on urine $\mathrm{N}$ content. These effects resulted in higher $\mathrm{N}$ faecal losses, especially those of the undigested dietary origin, without significant effects on potential $\mathrm{NH}_{3}$ emission. No significant interactions between CSP and OP supplementation were observed for the gaseous emissions measured.

\section{Introduction}

Intensive pig production is a major contributor to gaseous pollutant emissions. It has been estimated that in the EU it is responsible for 15 and $25 \%$ of the total ammonia $\left(\mathrm{NH}_{3}\right)$ and methane $\left(\mathrm{CH}_{4}\right)$ emissions (EEA, 2014a,b). It is widely recognized that pig slurry characteristics are heterogeneous depending on a number of factors including nutrition. Changes in slurry composition have been associated to gaseous emissions in previous research with modifications of dietary factors, as source and level of fibre (Canh et al., 1998b; Jarret et al., 2012), type of fibre (Triolo et al., 2011; Beccaccia et al., 2015a), level of protein (Canh et al., 1998a; Portejoie et al., 2004; Hernández et al., 2011) and source of protein (Beccaccia et al., 2015b).

Ether extract (EE) is the nutrient with the highest potential to generate $\mathrm{CH}_{4}$ from the slurry through microbial fermentation (Angelidakis and Sanders, 2004). Beccaccia et al. (2015c) reported that EE content in slurry samples from commercial farms increased $\mathrm{CH}_{4}$ emission potential, but reduced that of $\mathrm{NH}_{3}$. However, little is known about the relationships among feed composition, faecal fat concentration and gaseous emissions. Fat content in faeces has two origins: indigestible dietary EE, which is mainly related to the source of fat used in the feed as recognized in several research studies (Cera et al., 1989; Wiseman et al., 1990; Kil et al., 2010) and feeding tables (INRA, 2002; CVB, 2004; FEDNA, 2010), and endogenous losses that are generally associated with microbial synthesis in the gut. Previous studies (Kreuzer et al., 1999; Heimendahl et al., 2010) have found an increment of bacterial content in faeces when including a source of fermentable fibre in the diet, although the effects seem to be lesser when diets were compared at the same dietary neutral detergent fibre (NDF) content (Kreuzer et al., 1999; Beccaccia et al., 2015a). Otherwise, fat addition to the diet might hypothetically affect intestinal microbial activity and digestion efficiency of other dietary constituents.

The aim of the current research was to investigate changes in faecal fat concentration induced through supplementation with two industrial food by-products: calcium soap of palm fatty acids distillate and orange pulp, supplying respectively low digestible fat and fermentable fibre, and how these changes affect gaseous emissions from pig slurry.

\section{Material and methods}

\subsection{Animals and diets}

Thirty growing male pigs, progeny of Pietrain $\times$ (Landrace $\times$ Large White) were divided into three series (batches) of 10 animals each and used subsequently in this study. Average and standard deviation of body weight of pigs in batches 1,2 and 3 at allocation in metabolism pens were $54.0( \pm 1.46), 61.4( \pm 1.44)$ and $72.5( \pm 3.16) \mathrm{kg}$, respectively. A control diet $(C)$ was formulated with ingredients commonly used commercially in diets for growing-finishing pigs (wheat grain, barley grain, wheat bran and soybean meal). Another four experimental feeds were designed by substituting a mixture of wheat grain and calcium carbonate in the control diet (C) with increasing amounts (35 and $70 \mathrm{~g} / \mathrm{kg}$ ) of calcium soap of palm fatty acids distillate (CSP), alone or with further supplementation of $200 \mathrm{~g} / \mathrm{kg}$ orange pulp (OP) at each level of fat supplementation. The proportions of the other ingredients were also slightly modified to keep essential nutrient composition of diets above the recommendations of FEDNA (2006) for growing fattening pigs. In particular, levels of essential amino acids per unit of net energy (NE) were maintained as similar as possible among the experimental feeds. The analytical composition of the sample used of orange pulp was described in a companion paper (Beccaccia et al., 2015a); the sample of CSP contained 790 g/kg of $\mathrm{EE}, 190 \mathrm{~g} / \mathrm{kg}$ of ash and $90 \mathrm{~g} / \mathrm{kg}$ of Ca, with an estimated NE concentration of $24.5 \mathrm{MJ} / \mathrm{kg}$ (FEDNA, 2010). The ingredient and chemical composition of the experimental diets is presented in Tables 1 and 2, respectively. All diets had similar levels of crude protein (CP) and NDF, but the inclusion of CSP resulted in a slight increase in diet NE. Inclusion of OP increased soluble fibre (SF) content.

\subsection{Experimental procedures, sample preparation, chemical analyses and emissions measurements}

The general methodology used in this experiment has already been outlined in a companion paper (Beccaccia et al., 2015a).

\subsection{Statistical analysis}

Animal was the experimental unit for all the traits studied. The whole data set derived from the five dietary treatments was analyzed in a one factor analysis of variance as a completely randomized design with trial series, type of diet and its interaction as main effects by using PROC GLM of SAS (2008). The effects of diet were analyzed as a factorial arrangement 
Table 1

Ingredient composition of the control and experimental diets containing calcium soap of palm fatty acid distillate (CSP) and orange pulp (OP) ( $/ \mathrm{kg}$, as fed basis).

\begin{tabular}{|c|c|c|c|c|c|}
\hline & \multicolumn{5}{|l|}{ Diets $^{a}$} \\
\hline & Control & $35 \mathrm{CSP}$ & 70CSP & 35CSPOP & 70CSPOP \\
\hline Barley grain & 250 & 250 & 250 & 250 & 250 \\
\hline Wheat grain & 468 & 423 & 379 & 301 & 260 \\
\hline Wheat bran & 100 & 110 & 120 & 0 & 0 \\
\hline Cane molasses & 20.0 & 20.0 & 20.0 & 20.0 & 20.0 \\
\hline Soybean meal 45 & 132 & 137 & 141 & 176 & 182 \\
\hline Orange pulp & 0 & 0 & 0 & 200 & 200 \\
\hline $\operatorname{CSPP}^{\mathrm{a}}$ & 0 & 35.0 & 70.0 & 35.0 & 70.0 \\
\hline Calcium carbonate & 14.5 & 8.11 & 1.75 & 2.36 & 0 \\
\hline Sodium chloride & 1.11 & 1.50 & 1.89 & 1.27 & 1.23 \\
\hline Monosodium phosphate & 6.18 & 6.25 & 6.31 & 7.05 & 7.18 \\
\hline DL-methionine & 0.24 & 0.48 & 0.71 & 0.51 & 0.83 \\
\hline L-lysine HCL & 1.96 & 2.42 & 2.88 & 1.67 & 2.06 \\
\hline L-threonine & 0.43 & 0.71 & 0.98 & 0.45 & 0.70 \\
\hline L-tryptophan & 0 & 0.09 & 0.19 & 0.07 & 0.17 \\
\hline L-valine & 0 & 0.36 & 0.72 & 0.12 & 0.48 \\
\hline Premix ${ }^{\mathrm{b}}$ & 5.00 & 5.00 & 5.00 & 5.00 & 5.00 \\
\hline
\end{tabular}

a $35 \mathrm{CSP}=35 \mathrm{~g} / \mathrm{kg}$ of calcium soap of palm fatty acid distillate; $70 \mathrm{CSP}=70 \mathrm{~g} / \mathrm{kg}$ of calcium soap of palm fatty acid distillate; $35 \mathrm{CSPOP}=35 \mathrm{~g} / \mathrm{kg}$ of calcium soap of palm fatty acid distillate and $200 \mathrm{~g} / \mathrm{kg}$ of orange pulp; $70 \mathrm{CSPOP}=70 \mathrm{~g} / \mathrm{kg}$ of calcium soap of palm fatty acid distillate and $200 \mathrm{~g} / \mathrm{kg}$ of orange pulp.

b Vitamin and mineral premix supplied per kg complete diet: 5000 IU of vitamin A; 1000 IU of vitamin D3; 3 mg of vitamin B2; 20 mg of vitamin B12; 10 mg of niacin; $4 \mathrm{mg}$ of pantothenic acid; $48 \mathrm{mg}$ of betaine; $30 \mathrm{mg}$ of manganese oxide; $110 \mathrm{mg}$ of zinc oxide; $10 \mathrm{mg}$ of copper sulphate; $0.75 \mathrm{mg}$ of potassium iodide; $0.1 \mathrm{mg}$ sodium selenite; $90 \mathrm{mg}$ of iron carbonate.

Table 2

Chemical composition of the control and experimental diets containing calcium soap of palm fatty acid distillate (CSP) and orange pulp (OP) ( $\mathrm{g} / \mathrm{kg}$, as fed basis).

\begin{tabular}{|c|c|c|c|c|c|}
\hline & \multicolumn{5}{|l|}{ Diets $^{a}$} \\
\hline & Control & $35 \mathrm{CSP}$ & 70CSP & 35CSPOP & 70CSPOP \\
\hline Dry matter & 905 & 905 & 909 & 899 & 889 \\
\hline Ash & 45.0 & 46.4 & 47.8 & 49.4 & 52.1 \\
\hline Crude protein & 146 & 145 & 147 & 146 & 144 \\
\hline $\mathrm{NDICP}^{\mathrm{b}}$ & 16.1 & 15.8 & 21.0 & 20.9 & 26.3 \\
\hline Ether extract & 31.2 & 51.5 & 83.6 & 54.6 & 75.5 \\
\hline Soluble fibre ${ }^{c}$ & 28.4 & 44.0 & 37.7 & 95.6 & 106 \\
\hline aNDFom & 167 & 157 & 163 & 169 & 166 \\
\hline ADFom & 50.8 & 44.7 & 48.0 & 60.3 & 59.7 \\
\hline $\mathrm{ADL}$ & 11.0 & 8.20 & 9.40 & 7.90 & 8.10 \\
\hline Calcium $^{\mathrm{d}}$ & 6.60 & 7.30 & 8.00 & 8.00 & 10.2 \\
\hline Digestible phosphorous $^{\mathrm{d}}$ & 2.50 & 2.50 & 2.50 & 2.50 & 2.50 \\
\hline Sodium $^{\mathrm{d}}$ & 1.70 & 1.90 & 2.00 & 2.00 & 2.00 \\
\hline Chlorine $^{\mathrm{d}}$ & 2.10 & 2.40 & 2.70 & 2.10 & 2.10 \\
\hline Gross energy (MJ/kg) & 16.3 & 16.8 & 17.7 & 16.7 & 17.2 \\
\hline Net energy $(\mathrm{MJ} / \mathrm{kg})^{\mathrm{d}}$ & 9.20 & 9.75 & 10.3 & 9.41 & 9.91 \\
\hline \multicolumn{6}{|l|}{ Ileal digestible amino acids ${ }^{\mathrm{d}}$} \\
\hline Lysine & 7.10 & 7.50 & 7.90 & 7.20 & 7.60 \\
\hline Methionine & 2.20 & 2.40 & 2.60 & 2.30 & 2.60 \\
\hline Total sulphur & 4.60 & 4.70 & 4.90 & 4.50 & 4.70 \\
\hline Threonine & 4.60 & 4.80 & 5.10 & 4.70 & 4.90 \\
\hline Tryptophan & 1.50 & 1.60 & 1.70 & 1.60 & 1.70 \\
\hline Isoleucine & 4.90 & 4.90 & 4.90 & 5.00 & 5.00 \\
\hline Valine & 5.57 & 6.10 & 6.40 & 5.80 & 6.20 \\
\hline
\end{tabular}

a $35 \mathrm{CSP}=35 \mathrm{~g} / \mathrm{kg}$ of calcium soap of palm fatty acid distillate; $70 \mathrm{CSP}=70 \mathrm{~g} / \mathrm{kg}$ of calcium soap of palm fatty acid distillate; $35 \mathrm{CSPOP}=35 \mathrm{~g} / \mathrm{kg}$ of calcium soap of palm fatty acid distillate and $200 \mathrm{~g} / \mathrm{kg}$ of orange pulp; $70 \mathrm{CSPOP}=70 \mathrm{~g} / \mathrm{kg}$ of calcium soap of palm fatty acid distillate and $200 \mathrm{~g} / \mathrm{kg}$ of orange pulp.

b Neutral detergent insoluble crude protein.

c Calculated as total dietary fibre minus aNDFom corrected for NDICP.

d Values calculated according to FEDNA (2010).

by using orthogonal contrasts with level of CSP (35 or $70 \mathrm{~g} / \mathrm{kg}$ ) and inclusion of OP (0 or $200 \mathrm{~g} / \mathrm{kg}$ ) and its interaction as main effects. Contrasts of each of the experimental treatments against the control diet were done by using a Dunnett's test. Specific contrasts among means were done when needed. Cumulated $\mathrm{CH}_{4}$ evolution was analyzed by a repeated measures model using PROC MIXED of SAS (2008). Sources of variation included treatment, time, and the treatment $\times$ time interaction. The random variable was pig within treatment. Variables were analyzed subjected to 3 covariance structures: compound 
Table 3

Effects of including different levels of calcium soap of palm fatty acid distillate (CSP) with and without orange pulp (OP) in the diet fed pigs on the apparent digestibility coefficients and energy balance.

\begin{tabular}{|c|c|c|c|c|c|c|c|c|c|}
\hline & \multicolumn{5}{|l|}{ Diets $^{a}$} & \multirow[t]{2}{*}{ SEM $^{c}$} & \multicolumn{3}{|c|}{ Significance $^{\mathrm{b}}$} \\
\hline & Control & $35 \mathrm{CSP}$ & 70CSP & $35 \mathrm{CSPOP}$ & 70CSPOP & & CSP & OP & CSPxOP \\
\hline Dry matter & 0.830 & 0.856 & 0.817 & 0.843 & 0.816 & 0.008 & 0.001 & 0.394 & 0.462 \\
\hline Organic matter & 0.850 & 0.872 & 0.834 & 0.858 & 0.831 & 0.906 & $<0.001$ & 0.296 & 0.486 \\
\hline Gross energy & 0.822 & 0.833 & 0.800 & 0.827 & 0.794 & 0.008 & 0.001 & 0.474 & 0.992 \\
\hline Crude protein $^{\mathrm{d}}$ & 0.790 & 0.835 & 0.801 & 0.773 & 0.751 & 0.013 & 0.026 & $<0.001$ & 0.427 \\
\hline Ether extract $^{\mathrm{d}}$ & 0.574 & 0.669 & 0.603 & 0.625 & 0.547 & 0.023 & 0.006 & 0.044 & 0.795 \\
\hline Soluble fibre ${ }^{\text {d,e,f,g }}$ & 0.680 & 0.846 & 0.792 & 0.905 & 0.929 & 0.012 & 0.250 & $<0.001$ & 0.006 \\
\hline aNDFom $^{\mathrm{f}, \mathrm{g}}$ & 0.518 & 0.562 & 0.551 & 0.646 & 0.618 & 0.026 & 0.477 & 0.011 & 0.755 \\
\hline ADFom $^{\mathrm{f}, \mathrm{g}}$ & 0.372 & 0.388 & 0.388 & 0.571 & 0.561 & 0.031 & 0.879 & $<0.001$ & 0.862 \\
\hline Hemicelluloses & 0.563 & 0.613 & 0.593 & 0.667 & 0.620 & 0.028 & 0.140 & 0.039 & 0.636 \\
\hline Cellulose $^{f, g}$ & 0.398 & 0.455 & 0.437 & 0.639 & 0.631 & 0.030 & 0.670 & $<0.001$ & 0.871 \\
\hline DE-UE/DE ${ }^{\mathrm{h}}$ & 0.967 & 0.971 & 0.977 & 0.963 & 0.964 & 0.006 & 0.546 & 0.084 & 0.729 \\
\hline
\end{tabular}

a $35 \mathrm{CSP}=35 \mathrm{~g} / \mathrm{kg}$ of calcium soap of palm fatty acid distillate; $70 \mathrm{CSP}=70 \mathrm{~g} / \mathrm{kg}$ of calcium soap of palm fatty acid distillate; $35 \mathrm{CSPOP}=35 \mathrm{~g} / \mathrm{kg}$ of calcium soap of palm fatty acid distillate and $200 \mathrm{~g} / \mathrm{kg}$ of orange pulp; 70CSPOP $=70 \mathrm{~g} / \mathrm{kg}$ of calcium soap of palm fatty acid distillate and $200 \mathrm{~g} / \mathrm{kg}$ of orange pulp.

b $\mathrm{CSP}=$ effect increasing level of CSP from 35 to $70 \mathrm{~g} / \mathrm{kg}$; OP = effect of inclusion of $200 \mathrm{~g} / \mathrm{kg}$ orange pulp.

c Standard error of means $(n=6)$

d Contrast control vs 30CSP $(P<0.05)$

e Contrast control vs 70CSP $(P<0.05)$.

f Contrast control vs 35CSPOP $(P<0.05)$.

g Contrast control vs 70CSPOP $(P<0.05)$.

$\mathrm{h}$ Proportion of digestible energy not lost in urine.

symmetry, compound symmetry heterogeneous and autoregressive order 1. Using the largest Akaike information criterion and Schwarz Bayesian criterion, the compound symmetry was the structure that fitted the model best.

\section{Results}

\subsection{Coefficient of total tract apparent digestibility (CTTAD)}

Trial series had little influence on any of the traits studied and was excluded from the model. Results in Table 3 show that $\mathrm{EE}$ apparent digestibility decreased (by $11.1 \%, P=0.006$ ) when dietary level of CSP increased from 35 to $70 \mathrm{~g} / \mathrm{kg}$. This was associated with a decrease of DM, OM and gross energy (GE) apparent digestibility by 3.89, 3.76 and 3.98\% respectively. Level of CSP also decreased apparent digestibility of CP (by 3.48\%, $P=0.026$ ), but had no effect on SF, hemicelluloses (HEM) and cellulose (CEL). The inclusion of $200 \mathrm{~g} / \mathrm{kg}$ OP in the experimental feed also led to a decrease of EE apparent digestibility (by $7.9 \%, P=0.044$ ) and $\mathrm{CP}$ (by $6.85 \%, P<0.001$ ), but did not affect those of DM, OM or GE because of a simultaneous increase of the apparent digestibility of SF, HEM and CEL (by 12.0, 8.11 and $42.3 \%$, respectively, $P<0.05$ ). In the case of SF digestibility, a significant interaction was observed $(P=0.006)$, as the improved efficiency observed with OP was greater at the highest level of CSP. Compared with the control diet all treatments increased the CTTAD of SF. The CTTAD of CP and EE were only increased relative to the control diet in pigs fed the 35CSP diet. Otherwise, SF and CEL digestibility improved with respect to diet $C$ with OP addition at any level of CSP. Energy losses in urine expressed as a proportion of digestible energy were not affected by treatments and averaged 0.032 .

\subsection{Composition of effluents}

The effect of treatments on the excreta composition is shown in Table 4. Increasing CSP from 35 to $70 \mathrm{~g} / \mathrm{kg}$ greatly increased (by $48.9 \%, P<0.001$ ) faecal EE content, but decreased those of aNDFom, ADL, HEM and CEL (by 15.1, 15.0, 12.0 and 14.5\%, $P<0.003)$. The degree of lignification of NDF in the faecal output was close to 0.108 at both CSP levels. Addition of $200 \mathrm{~g} / \mathrm{kg}$ of OP to the diet increased $(P=0.012)$ faecal content of $\mathrm{EE}$ (by $7.27 \%$ ) and CP (by $29.6 \%, P<0.001$ ) and decreased $(P<0.001)$ HEM, CEL and aNDFom contents (by 19.5, 11.9 and 16.3\%). A lesser effect was observed on ADL faecal concentration $(P=0.057)$, so that the degree of lignification of NDF tended to increase with OP addition (from 0.104 to 0.113 ). Treatments did not affect faecal concentration of SF (that was low, averaging $53.6 \mathrm{~g} / \mathrm{kg} \mathrm{DM}$ ), neither those of DM and $\mathrm{N}$ in urine (mean values of $60.7 \mathrm{~g} / \mathrm{kg}$ and $121 \mathrm{~g} / \mathrm{kg} \mathrm{DM})$. Instead, a trend for an interaction $(P=0.066)$ was found on faecal $\mathrm{pH}$, as its increase with OP inclusion $(P=0.005)$ was greater at the highest level of addition of CSP.

Compared to the control faecal EE was increased by all treatments, faecal CP was increased in pigs fed the 35CSPOP diet and aNDF, and HEM and CEL were lower in pigs fed diets 70CSP and the two diets supplemented with OP. 
Effects of including different levels of calcium soap of palm fatty acid distillate (CSP) with and without orange pulp (OP) in the diet fed pigs on faeces and urine composition (g/kg DM).

\begin{tabular}{|c|c|c|c|c|c|c|c|c|c|}
\hline & \multicolumn{5}{|l|}{ Diets $^{\mathrm{a}}$} & \multirow[t]{2}{*}{$\mathrm{SEM}^{\mathrm{c}}$} & \multicolumn{3}{|c|}{ Significance $^{b}$} \\
\hline & Control & $35 \mathrm{CSP}$ & 70CSP & 35CSPOP & 70CSPOP & & CSP & $\mathrm{OP}$ & CSPxOP \\
\hline \multicolumn{10}{|l|}{ Faeces } \\
\hline Dry matter & 378 & 345 & 363 & 375 & 362 & 13.6 & 0.861 & 0.308 & 0.266 \\
\hline Organic matter ${ }^{\mathrm{d}, \mathrm{e}}$ & 836 & 844 & 857 & 850 & 844 & 2.77 & 0.200 & 0.244 & 0.053 \\
\hline Ether extract ${ }^{\mathrm{d}, \mathrm{e}, \mathrm{f}, \mathrm{g}}$ & 85.8 & 131 & 199 & 145 & 209 & 4.16 & $<0.001$ & 0.012 & 0.659 \\
\hline Crude protein $^{\mathrm{e}}$ & 198 & 172 & 176 & 234 & 217 & 6.85 & 0.362 & $<0.001$ & 0.156 \\
\hline Soluble fibre & 59.2 & 52.0 & 47.0 & 63.5 & 45.6 & 8.48 & 0.469 & 0.731 & 0.686 \\
\hline aNDFom & 521 & 527 & 439 & 423 & 386 & 11.5 & $<0.001$ & $<0.001$ & 0.056 \\
\hline ADFom $^{f, g}$ & 199 & 210 & 176 & 183 & 160 & 5.16 & $<0.001$ & $<0.001$ & 0.301 \\
\hline $\mathrm{ADL}$ & 50.1 & 55.0 & 45.5 & 48.8 & 42.7 & 2.18 & 0.003 & 0.057 & 0.445 \\
\hline Hemicelluloses $^{\mathrm{d}, \mathrm{e}, \mathrm{g}}$ & 322 & 317 & 263 & 240 & 227 & 9.08 & 0.002 & $<0.001$ & 0.041 \\
\hline Cellulose $^{\mathrm{d}, \mathrm{e}, \mathrm{g}}$ & 149 & 155 & 130 & 134 & 117 & 3.95 & $<0.001$ & $<0.001$ & 0.348 \\
\hline \multicolumn{10}{|l|}{ Urine } \\
\hline Dry matter & 72.9 & 63.5 & 47.6 & 55.2 & 67.2 & 7.69 & 0.793 & 0.483 & 0.092 \\
\hline Total Kjeldahl N & 138 & 131 & 119 & 110 & 105 & 9.34 & 0.377 & 0.087 & 0.696 \\
\hline
\end{tabular}

a $35 \mathrm{CSP}=35 \mathrm{~g} / \mathrm{kg}$ of calcium soap of palm fatty acid distillate; $70 \mathrm{CSP}=70 \mathrm{~g} / \mathrm{kg}$ of calcium soap of palm fatty acid distillate; $35 \mathrm{CSPOP}=35 \mathrm{~g} / \mathrm{kg}$ of calcium soap of palm fatty acid distillate and $200 \mathrm{~g} / \mathrm{kg}$ of orange pulp; $70 \mathrm{CSPOP}=70 \mathrm{~g} / \mathrm{kg}$ of calcium soap of palm fatty acid distillate and $200 \mathrm{~g} / \mathrm{kg}$ of orange pulp.

b $\mathrm{CSP}=$ effect increasing level of CSP from 35 to $70 \mathrm{~g} / \mathrm{kg}$; OP = effect of inclusion of $200 \mathrm{~g} / \mathrm{kg}$ orange pulp.

c Standard error of means $(n=6)$.

d Contrast control vs 70CSP $(P<0.05)$.

e Contrast control vs 35CSPOP $(P<0.05)$.

f Contrast control vs 35CSP $(P<0.05)$.

g Contrast control vs 70CSPOP $(P<0.05)$.

Table 5

Effects of including different levels of calcium soap of palm fatty acid distillate (CSP) with and without orange pulp (OP) in the diet fed pigs on daily DM and $\mathrm{N}$ balance and on the proportion of faecal $\mathrm{N}$ fractions.

\begin{tabular}{|c|c|c|c|c|c|c|c|c|c|}
\hline & \multicolumn{5}{|l|}{ Diets $^{\mathrm{a}}$} & \multirow[t]{2}{*}{ SEM $^{\mathrm{c}}$} & \multicolumn{3}{|c|}{ Significance $^{\mathrm{b}}$} \\
\hline & Control & $35 \mathrm{CSP}$ & 70CSP & 35CSPOP & 70CSPOP & & CSP & $\mathrm{OP}$ & CSPxOP \\
\hline Body weight, kgd & 62.5 & 61.5 & 65.0 & 61.4 & 62.8 & 0.351 & 0.001 & 0.081 & 0.114 \\
\hline \multicolumn{10}{|l|}{ DM balance $\left(\mathrm{g} / \mathrm{kg}^{0.75}\right)$} \\
\hline Intake & 73.9 & 70.0 & 76.2 & 67.9 & 69.1 & 3.67 & 0.323 & 0.225 & 0.499 \\
\hline Faeces & 12.3 & 10.0 & 13.8 & 10.7 & 12.8 & 0.644 & $<0.001$ & 0.750 & 0.216 \\
\hline Urine & 3.48 & 2.95 & 2.51 & 3.67 & 3.51 & 0.416 & 0.478 & 0.057 & 0.735 \\
\hline \multicolumn{10}{|l|}{$N$ balance $\left(\mathrm{g} / \mathrm{kg}^{0.75}\right)$} \\
\hline Intake & 1.90 & 1.79 & 1.98 & 1.77 & 1.79 & 0.095 & 0.305 & 0.278 & 0.419 \\
\hline Faeces & 0.395 & 0.277 & 0.389 & 0.404 & 0.452 & 0.034 & 0.031 & 0.014 & 0.368 \\
\hline Urine & 0.446 & 0.383 & 0.296 & 0.419 & 0.354 & 0.052 & 0.167 & 0.384 & 0.841 \\
\hline Retained & 1.06 & 1.14 & 1.29 & 0.946 & 0.984 & 0.083 & 0.267 & 0.009 & 0.495 \\
\hline \multicolumn{10}{|c|}{$N$ fractions in faeces ( $g / g$ total faecal $N$ ) } \\
\hline $\mathrm{UDN}^{\mathrm{e}, \mathrm{f}, \mathrm{g}}$ & 8.72 & 7.20 & 6.18 & 19.7 & 20.2 & 2.46 & 0.982 & $<0.001$ & 0.681 \\
\hline $\mathrm{BEDN}^{\mathrm{e}, \mathrm{f}, \mathrm{h}}$ & 65.8 & 58.6 & 62.4 & 50.9 & 48.3 & 3.21 & 0.963 & 0.005 & 0.294 \\
\hline $\mathrm{WSN}^{\mathrm{i}}$ & 25.5 & 34.2 & 31.4 & 29.3 & 31.5 & 1.86 & 0.926 & 0.266 & 0.199 \\
\hline
\end{tabular}

a $35 \mathrm{CSP}=35 \mathrm{~g} / \mathrm{kg}$ of calcium soap of palm fatty acid distillate; $70 \mathrm{CSP}=70 \mathrm{~g} / \mathrm{kg}$ of calcium soap of palm fatty acid distillate; $35 \mathrm{CSPOP}=35 \mathrm{~g} / \mathrm{kg}$ of calcium soap of palm fatty acid distillate and $200 \mathrm{~g} / \mathrm{kg}$ of orange pulp; $70 \mathrm{CSPOP}=70 \mathrm{~g} / \mathrm{kg}$ of calcium soap of palm fatty acid distillate and $200 \mathrm{~g} / \mathrm{kg}$ of orange pulp.

b $\mathrm{CSP}=$ effect of level of inclusion of CSP; OP = effect of inclusion of $200 \mathrm{~g} / \mathrm{kg}$ of orange pulp.

c Standard error of means $(n=6)$.

d Contrast control vs 70CSP $(P<0.05)$.

e Contrast control vs 35CSPOP $(P<0.05)$.

f Contrast control vs 70CSPOP $(P<0.05)$.

$g$ Undigested dietary nitrogen.

h Bacterial and endogenous debris nitrogen.

i Water soluble nitrogen.

\subsection{Dry matter and nitrogen flows}

The DM and $\mathrm{N}$ daily balances and the separation of faecal $\mathrm{N}$ in fractions for each of the experimental diets are presented in Table 5. Values are expressed per kg of metabolic weight to correct slight differences among treatments besides to the general increase of pig weight throughout the successive trial series. Treatments did not affect daily DM or N intake which averaged 71.4 and $1.85 \mathrm{~g} / \mathrm{kg}^{0.75}$, respectively. Increasing CSP level from 35 to $70 \mathrm{~g} / \mathrm{kg}$ increased faecal DM excretion (from 10.3 to $13.3 \mathrm{~g} / \mathrm{kg}^{0.75}$ and day, $P<0.001$ ) and $\mathrm{N}$ excretion in faeces (from 0.333 to $0.389, P=0.034$ ). CSP level had no effect on $\mathrm{N}$ excreted in urine or the proportions of faecal $\mathrm{N}$ fractions. Inclusion of $\mathrm{OP}$ in the experimental feeds tended $(P=0.057)$ to increase DM excretion in urine (from 2.73 to $3.59 \mathrm{~g} / \mathrm{kg}^{0.75}$ and day), but not that of faecal DM. Addition of OP had no significant 
Effects of including different levels of calcium soap of palm fatty acid distillate (CSP) with and without orange pulp (OP) in the diet fed pigs on slurry (faeces + urine) excretion, initial characteristics and derived ammonia $\left(\mathrm{NH}_{3}\right)$ emission and biochemical methane potential $\left(\mathrm{B}_{0}\right)$.

\begin{tabular}{|c|c|c|c|c|c|c|c|c|c|}
\hline & \multicolumn{5}{|l|}{ Diets $^{\mathrm{a}}$} & \multirow[t]{2}{*}{ SEM $^{\mathrm{c}}$} & \multicolumn{3}{|c|}{ Significance $^{b}$} \\
\hline & Control & $35 \mathrm{CSP}$ & 70CSP & 35CSPOP & 70CSPOP & & CSP & OP & CSPxOP \\
\hline Slurry excretion (kg/d) & 1.89 & 1.78 & 2.19 & 2.10 & 2.04 & 0.153 & 0.286 & 0.602 & 0.141 \\
\hline \multicolumn{10}{|l|}{ Slurry characteristics } \\
\hline $\mathrm{DM}(\mathrm{g} / \mathrm{kg})$ & 167 & 146 & 166 & 135 & 144 & 13.1 & 0.279 & 0.203 & 0.686 \\
\hline $\mathrm{OM}(\mathrm{g} / \mathrm{kg})$ & 134 & 119 & 138 & 108 & 114 & 11.0 & 0.261 & 0.130 & 0.568 \\
\hline Total ammonial N (g/L) & 3.61 & 3.43 & 2.81 & 3.04 & 3.06 & 0.568 & 0.605 & 0.905 & 0.589 \\
\hline Total Kjeldahl N (TKN, g/kg) & 10.2 & 8.99 & 8.31 & 8.79 & 8.84 & 0.674 & 0.622 & 0.791 & 0.566 \\
\hline $\mathrm{pH}^{\mathrm{d}}$ & 8.52 & 8.08 & 7.65 & 8.13 & 8.18 & 0.183 & 0.354 & 0.157 & 0.239 \\
\hline Total volatile fatty acids (mmol/L) & 86.0 & 69.7 & 90.6 & 75.9 & 96.2 & 7.82 & 0.020 & 0.481 & 0.971 \\
\hline Acetic acid (mmol/L) & 55.5 & 44.4 & 57.4 & 49.7 & 62.8 & 4.79 & 0.018 & 0.306 & 0.989 \\
\hline Propionic acid (mmol/L) & 14.4 & 12.4 & 15.6 & 12.0 & 14.8 & 1.63 & 0.088 & 0.718 & 0.895 \\
\hline Butyric acid (mmol/L) & 7.86 & 6.63 & 9.75 & 7.25 & 9.72 & 1.67 & 0.119 & 0.865 & 0.852 \\
\hline \multicolumn{10}{|l|}{ Gas emissions } \\
\hline \multicolumn{10}{|l|}{ Ammonia emission assay } \\
\hline $\mathrm{g} \mathrm{NH}_{3 /} \mathrm{kg}$ slurry ${ }^{\mathrm{d}, \mathrm{e}, \mathrm{f}, \mathrm{g}}$ & 2.41 & 2.32 & 1.59 & 1.80 & 1.77 & 0.188 & 0.036 & 0.332 & 0.053 \\
\hline 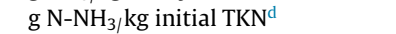 & 193 & 218 & 162 & 182 & 166 & 21.3 & 0.144 & 0.504 & 0.399 \\
\hline $\mathrm{mg} \mathrm{NH}_{3} /$ animal and day ${ }^{\mathrm{h}}$ & 412 & 399 & 331 & 373 & 341 & 43.0 & 0.298 & 0.879 & 0.707 \\
\hline \multicolumn{10}{|l|}{ Biochemical methane potential } \\
\hline $\mathrm{B}_{0}, \mathrm{~mL}$ methane/g $\mathrm{OM}^{\mathrm{g}}$ & 305 & 313 & 357 & 346 & 406 & 19.0 & 0.021 & 0.063 & 0.690 \\
\hline L-methane/animal and day ${ }^{\mathrm{d}}$ & 77.8 & 68.7 & 109 & 70.6 & 96.9 & 5.89 & $<0.001$ & 0.419 & 0.276 \\
\hline
\end{tabular}

a $35 \mathrm{CSP}=35 \mathrm{~g} / \mathrm{kg}$ of calcium soap of palm fatty acid distillate; $70 \mathrm{CSP}=70 \mathrm{~g} / \mathrm{kg}$ of calcium soap of palm fatty acid distillate; $35 \mathrm{CSPOP}=35 \mathrm{~g} / \mathrm{kg}$ of calcium soap of palm fatty acid distillate and $200 \mathrm{~g} / \mathrm{kg}$ of orange pulp; 70CSPOP $=70 \mathrm{~g} / \mathrm{kg}$ of calcium soap of palm fatty acid distillate and $200 \mathrm{~g} / \mathrm{kg}$ of orange pulp.

b $\mathrm{CSP}=$ effect increasing level of CSP from 35 to $70 \mathrm{~g} / \mathrm{kg}$; OP = effect of inclusion of $200 \mathrm{~g} / \mathrm{kg}$ orange pulp.

c Standard error of means $(n=6)$.

d Cumulated (11 days).

e Contrast Control vs 70CSP $(P<0.05)$.

f Contrast Control vs 35CSPOP $(P<0.05)$.

g Contrast Control vs 70CSPOP $(P<0.05)$.

h $24-\mathrm{h} \mathrm{NH}_{3}$ emission from the slurry produced by one animal in one day.

influence on $\mathrm{N}$ excretion in urine, but increased $\mathrm{N}$ in faeces (from 0.333 to $0.428 \mathrm{~g} / \mathrm{kg}^{0.75}$ and day, $P=0.014$ ). Inclusion of OP in the diet affected the proportion of $\mathrm{N}$ fractions. Undigested $\mathrm{N}$ (UDN) increased, whereas bacterial and endogenous debris nitrogen (BEDN) decreased. No significant effects of treatments were observed on the proportion of water soluble nitrogen fraction.

When comparisons were made against the control diet, results showed that BEDN proportion on faecal $\mathrm{N}$ decreased in OP diets, in parallel to an increase in UDN fraction.

\subsection{Slurry characteristics and gaseous emissions}

Water intake during the collection period was not affected by treatments, and averaged $3.69 \pm 1.14$ (SD) $\mathrm{kg} / \mathrm{d}$. Neither slurry excretion nor the initial slurry characteristics (DM, OM, total ammonia N (TAN), total Kjeldahl N (TKN) and pH) were significantly affected by treatment (Table 6). However, total volatile fatty acids (VFA) were higher at CSP inclusion rate of $70 \mathrm{~g} / \mathrm{kg}$ than at $35 \mathrm{~g} / \mathrm{kg}(P=0.020)$. This effect was parallel for acetic, propionic and butiric acid, although differences only reached significant levels in the case of acetic acid $(P=0.018)$. Ammonia emission from slurry $\left(\mathrm{g} \mathrm{NH}_{3} / \mathrm{kg}\right)$ was lower in diets formulated with higher levels of $\operatorname{CSP}(P=0.036)$ but was not affected by OP inclusion. A trend $(P=0.053)$ was detected for an interaction between treatments on this trait, as the effect of CSP was greater when no OP was added to diets.

When slurry characteristics and the derived gaseous emission were compared with treatment $\mathrm{C}$, a lower $\mathrm{pH}$ on diet 70CSP was observed $(P<0.05)$; additionally, $\mathrm{NH}_{3}$ emission per $\mathrm{kg}$ of slurry was lower $(P<0.05)$ in treatments 70CSP, 35CSPOP and 70 CSPOP.

Increasing CSP from 35 to $70 \mathrm{~g} / \mathrm{kg}$ increased potential $\mathrm{CH}_{4}$ emission $\left(\mathrm{B}_{0}\right)$ from the slurry $(P=0.021)$ and the volume of $\mathrm{CH}_{4}$ emitted per animal and day $(P<0.001)$. The inclusion of OP did not affect significantly any of these traits. Fig. 1 shows the evolution of the cumulated $\mathrm{CH}_{4}$ emission with time in the $\mathrm{B}_{0}$ assay. At day 17 of study, treatments 70CSP and 70CSPOP showed a higher cumulated $\mathrm{CH}_{4}$ production with respect to the other treatments $(P<0.05)$. From day 24 until the end of the study, treatment 70CSPOP led to higher cumulated $\mathrm{CH}_{4}$ values than both $35 \mathrm{CSP}$ treatments, with diet 70CSP giving intermediate results. On the other hand, treatment $\mathrm{C}$ showed the lowest cumulated $\mathrm{CH}_{4}$ values, although they were not different from both 35 CSP diets. 


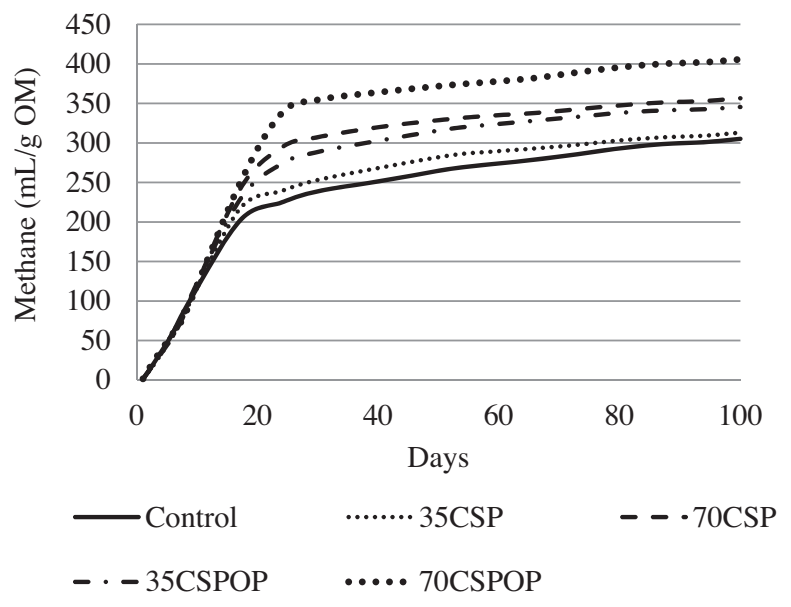

Fig. 1. Effect of treatments on cumulated methane emission potential from slurry over 100 days $(\mathrm{SD}=20.1 \mathrm{~mL} / \mathrm{g} \mathrm{OM})$. Treatments are: $35 \mathrm{CSP}=35 \mathrm{~g} / \mathrm{kg}$ of calcium soap of palm fatty acid distillate; $70 \mathrm{CSP}=70 \mathrm{~g} / \mathrm{kg}$ of calcium soap of palm fatty acid distillate; $35 \mathrm{CSPOP}=35 \mathrm{~g} / \mathrm{kg}$ of calcium soap of palm fatty acid distillate and $200 \mathrm{~g} / \mathrm{kg}$ of orange pulp; $70 \mathrm{CSPOP}=70 \mathrm{~g} / \mathrm{kg}$ of calcium soap of palm fatty acid distillate and $200 \mathrm{~g} / \mathrm{kg}$ of orange pulp. At day 17 , inclusion of 70 vs $35 \mathrm{~g} \mathrm{CSP} / \mathrm{kg}$ led to increasing methane emission $(P<0.05)$. Beyond day 24 , treatment $70 \mathrm{CSPOP}$ had higher $(P<0.05)$ values than both $35 \mathrm{CSP}$ diets, with 70CSP diet giving intermediate results. Both 70CSP treatments led to higher values $(P<0.05)$ than the control diet from $\mathrm{d} 17$ onwards.

\section{Discussion}

Our results showed that the addition of CSP and OP in a practical type diet altered the digestibility of nutrients, the composition of slurry and $\mathrm{CH}_{4}$ and $\mathrm{NH}_{3}$ potential emissions. Increasing the level CSP from zero to 35 and $70 \mathrm{~g} / \mathrm{kg}$ increased faecal EE content from 85.8 to 138 and to $204 \mathrm{~g} / \mathrm{kg}$ DM respectively. The increases were associated with the higher EE content and the limited EE digestibility of CSP in the supplemented diets. The low digestibility of CSP EE was likely associated with the high percentage of palmitic acid and low ratio of polyunsaturated to saturated fatty acids in palm oil (Wiseman and Cole, 1983; Powles et al., 1993; FEDNA, 2010). Compared to the control diet, animals from the group 35CSP showed a higher EE apparent digestibility. There are two possible explanations for this effect. One is that, as suggested by some authors (Bakker et al., 1995; Leek et al., 2004; Cerisuelo et al., 2012), lipid digestibility in fat sources (even CSP) is higher than that of the lipid contained in other feedstuffs. As the digestibility of EE fraction of CSP is limited, this increase in EE digestibility with CSP addition (as a fat source) is only observed when comparing the control diet ( $0 \mathrm{CSP} \mathrm{g} / \mathrm{kg}$ ) with a diet with moderate CSP inclusion levels $(35 \mathrm{~g} / \mathrm{kg}$ ). On the other hand, our results also indicate that the control diet has the highest BEDN (bacterial and endogenous debris N) proportion in faeces. This suggests that control treatment might have a proportionately increased contribution of bacterial/endogenous lipid to faecal output and, as a consequence, an apparent decrease of EE digestibility compared to other treatments, especially 35CSP.

Inclusion of $200 \mathrm{~g} / \mathrm{kg}$ of OP also led to a significant (although lesser than for CSP) increment of faecal EE content (from 165 to $177 \mathrm{~g} / \mathrm{kg} \mathrm{DM}$ ), associated with reduced apparent EE digestibility (from 63.6 to 58.6\%). This result might be explained by higher fat endogenous losses (Kil et al., 2010). Fermentable fibre is an energy source available for hindgut flora in the pig, so that an increase of low-lignified cell wall constituents in the diet might result in higher gut microbial growth (Canh et al., 1997; Bindelle et al., 2009; Heimendahl et al., 2010). Inclusion of OP in the diet could therefore imply an increased faecal excretion of microbial fat, which would reduce its apparent faecal digestibility. However, OP inclusion did not affect significantly daily faecal BEDN excretion in the current study, as the higher faecal $\mathrm{N}$ excretion was compensated with a lower proportion of BEDN fraction in the faecal $\mathrm{N}$. The present results confirm those previously obtained using the same methodology by Kreuzer et al. (1999) and Beccaccia et al. (2015a), when inclusion of fermentable fibre was compared in diets containing similar levels of NDF. Otherwise, our results agree with those obtained by Bach Knudsen and Hansen (1991) who observed a decrease of ileal and faecal digestibility of fat when level of soluble fibre in the diet increased. These authors suggested that this was associated with depressed absorption of dietary fat and a lower resorption of bile acids. Because of its high digestibility faecal content of SF was unaffected by treatments, as also occurred in previous studies (Graham et al., 1986; Canibe and Bach Knudsen, 1997; Beccaccia et al., 2015a,b).

Overall, increasing the level of CSP in the diet increased faecal EE content and excretion and resulted in a greater $\mathrm{CH}_{4}$ emission potential. The increase in emission potential occurred despite a concomitant decline in faecal aNDFom content. This result can be explained by the theoretical estimations of Angelidakis and Sanders (2004) of the $\mathrm{CH}_{4}$ yield from lipids relative to other slurry components. Beccaccia et al. (2015c) also observed higher potential $\mathrm{CH}_{4}$ emissions in slurry from nursery pigs, characterized by a higher EE content than in other classes of pigs (growing-finishing or adults). Despite causing similar modifications of excreta composition as CSP, the increase in $\mathrm{CH}_{4}$ potential emissions with dietary OP inclusion observed in the current study did not reach significance $(P=0.063)$. This might be related to the lower influence of OP with respect to CSP on faecal EE concentration. In the literature, the inclusion of different fibre sources such as dry distillers grains with 
solubles, sugar beet pulp or rapeseed meal led to variable effects on faecal or slurry $\mathrm{B}_{0}$ (Jarret et al., 2011a, 2011b, 2012; Torres-Pitarch et al., 2014; Beccaccia et al., 2015a) according to differences in fibre, EE or CP content in the slurry. In most of the studies higher fibre levels were associated with higher fat levels to achieve isoenergetic feeds. The results of the present experiment suggest that, if this is the case, the effects frequently attributed to fibre supplementation might be confounded with those related to a higher dietary and faecal EE content.

In our study, including $200 \mathrm{~g} / \mathrm{kg}$ OP in the diet increased the CP content of faecal DM by $29 \%$ and was associated with a decline in apparent $\mathrm{CP}$ digestibility by $7 \%$. These results are in agreement with previous research with OP in pigs (Beccaccia et al., 2015a) and might be explained by the synthesis of Maillard compounds because of the high sugar content of this feedstuff and the high temperature reached during the dehydration process. Addition of OP also increased $\mathrm{N}$ excreted daily in faeces, but did not affect significantly $\mathrm{N}$ excretion in urine. Consequently, more total $\mathrm{N}$ was excreted with OP supplementation $\left(0.864 \mathrm{vs} 0.673 \mathrm{~g} / \mathrm{kg}^{0.75}, P=0.050\right)$ and the ratio of $\mathrm{N}$ excreted in faeces: urine increased by $5.15 \%$ compared to treatments without OP addition, although this difference in the ratio did not reach significance. Otherwise, increasing CSP dietary inclusion from 35 to $70 \mathrm{~g} / \mathrm{kg}$ did not affect $\mathrm{N}$ concentration in faeces or urine neither daily $\mathrm{N}$ urine losses but significantly increased $\mathrm{N}$ excretion in faeces, and therefore the ratio faecal: urine $\mathrm{N}$ (from 0.83 to $1.14, P=0.014$ ). Otherwise, an unexpected lower $\mathrm{N}$ retention in the diets with OP was observed. This result might be related to an overvaluation of amino acid digestibility that showed a marked lower CP digestibility compared with the rest of treatments.

An interaction $(P=0.053)$ between CSP inclusion level and the inclusion of OP on ammonia emission was detected, as the addition of CSP reduced $\mathrm{NH}_{3}$ potential emission only when OP was not included in the diet. The main factors related to slurry composition which influence $\mathrm{NH}_{3}$ emissions are the amount of TAN, the $\mathrm{pH}$ and the ratio of $\mathrm{N}$ excreted in faeces: urine. In the present study, the amount of TAN and the $\mathrm{pH}$ were not different among treatments, despite the fact that treatments with the highest CSP inclusion level $(70 \mathrm{~g} / \mathrm{kg}$ ) showed the greatest VFA concentration in the slurry. Instead, faecal:urine $\mathrm{N}$ ratio increased with CSP addition in a greater extent $(+81 \mathrm{vs}+32 \%)$ when OP was not included in the diet. This ratio is inversely related to $\mathrm{NH}_{3}$ emissions because urinary $\mathrm{N}$ is more easily volatilized than organic $\mathrm{N}$ (Canh et al., 1997; Nahm, 2003). To the authors' knowledge, processes which may explain the effect of dietary fat content reducing $\mathrm{NH}_{3}$ emissions have not been described in the literature. Beccaccia et al. (2015c) reported a negative effect of slurry EE content on $\mathrm{NH}_{3}$ emission from commercial pig slurries when expressed per g of OM content. However, Leek et al. (2004) did not observe any effect of type or level of dietary oil on $\mathrm{N}$ balance or $\mathrm{NH}_{3}$ emission from the slurry, but faecal EE concentration was not provided and might not differ as sources of fat used were more digestible than in our study. Otherwise, several studies in the literature suggest that the inclusion of dietary sources of soluble fibre led to an increase of faecal:urine $\mathrm{N}$ ratio in the slurry and a decrease in the $\mathrm{NH}_{3}$ emission rates (Canh et al., 1998b; Jarret et al., 2012). However, as in the case of $\mathrm{CH}_{4}$, this effect which is frequently attributed to fibre supplementation might be also associated with the parallel increase in fat content of the diets and excreta. Additionally, according to the results obtained in the present study, the relation between slurry EE content and the potential $\mathrm{NH}_{3}$ emission could have another explanation. The observed increase of VFA concentration with CSP addition might be related with the formation of new microbial tissue in the slurries derived from these diets. As suggested by McCrory and Hobbs (2001) and other studies, microorganisms might contribute to $\mathrm{N}$ immobilization and the reduction of $\mathrm{NH}_{3}$ volatilization in livestock wastes. However, the definitive cause remains to be established and further research would seem warranted.

\section{Conclusions}

In all, inclusion of two industrial by-products, CSP and OP in isonutritive diets induced significant changes in slurry composition. However, only CSP influenced gaseous emission, increasing $\mathrm{B}_{0}$ and volume of $\mathrm{CH}_{4}$ per animal and day, and decreasing $\mathrm{NH}_{3}$ per kg of slurry. These results enhance the interest of modelling characteristics of slurry, as it constitutes the substrate for gaseous emissions. This information might then be used as a tool to manipulate microbial fermentation in order to minimize $\mathrm{CH}_{4}$ and $\mathrm{NH}_{3}$ losses.

\section{Conflict of interest statement}

All authors disclose not to have any actual or potential conflict of interest including any financial, personal or other relationship with other people or organizations on the submitted work that could inappropriately influence, or be perceived to influence, their work.

\section{Acknowledgements}

This project was funded by the Spanish Ministry of Science and Innovation (AGL2011-30023) and the Valencian Government (ACOMP/2013/118). We also thank CAPES Foundation, Ministry of Education of Brazil, Brasilia - DF 70040-020, Brazil for a research fellowship grant.

\section{References}

Angelidakis, I., Sanders, W., 2004. Assessment of the anaerobic biodegradability of macropollutants. Rev. Environ. Sci. Biotechnol. 3, 117-129. 
Bach Knudsen, K.E., Hansen, I., 1991. Gastrointestinal implications in pigs of wheat and oat fractions. 1. Digestibility and bulking properties of polysaccharides and other major constituents. Br. J. Nutr. 65, 217-232.

Bakker, G.C.M., Jongbloed, R., Verstegen, M.W.A., Jongbloed, A.W., Bosch, M.W., 1995. Nutrient apparent digestibility and the performance of growing fattening pigs as affected by incremental additions of fat to starch or non-starch polysaccharides. Anim. Sci. 60, 325-335.

Beccaccia, A., Calvet, S., Cerisuelo, A., Ferrer, P., García-Rebollar, P., De Blas, C., 2015a. Effects of nutrition on digestion efficiency and gaseous emissions from slurry in growing-finishing pigs. I. Influence of the inclusion of two levels of orange pulp and carob meal in isofibrous diets. Anim. Feed Sci. Technol. 208, 158-169.

Beccaccia, A., Cerisuelo, A., Calvet, S., Ferrer, P., Estellés, F., De Blas, C., García-Rebollar, P., 2015b. Effects of nutrition on digestion efficiency and gaseous emissions from slurry in growing pigs: II. Effect of protein source in practical diets. Anim. Feed Sci. Technol. $209,137-144$.

Beccaccia, A., Ferrer, P., Ibáñez, M.A., Estellés, F., Rodríguez, C., Moset, V., De Blas, C., Calvet, S., García-Rebollar, P., 2015c. Relationships among slurry characteristics and gaseous emissions at different types of commercial Spanish pig farms. Span. J. Agric. Res. 13, e06-002, 15 pp.

Bindelle, J., Buldgen, A., Delacollette, M., Wavreille, J., Agneessens, R., Destain, J.P., Leterme, P., 2009. Influence of source and concentrations of dietary fiber on in vivo nitrogen excretion pathways in pigs as reflected by in vitro fermentation and nitrogen incorporation by fecal bacteria. J. Anim. Sci. 87 , 583-593.

Canh, T.T., Verstegen, M.W.A., Aarnink, A.J.A., Schrama, J.W., 1997. Influence of dietary factors on nitrogen partitioning and composition of urine and faeces of fattening pigs. J. Anim. Sci. 75, 700-706.

Canh, T.T., Aarnink, A.J.A., Schutte, J.B., Sutton, A., Langhout, D.J., Verstegen, M.W.A., 1998a. Dietary protein affects nitrogen excretion and ammonia emission from slurry of growing-finishing pigs. Livest. Prod. Sci. 56, 181-191.

Canh, T.T., Sutton, A.L., Aarnink, A.J.A., Verstegen, M.W.A., Schrama, J.W., Bakker, G.C.M., 1998b. Dietary carbohydrates alter the fecal composition and pH and the ammonia emission from slurry of growing pigs. J. Anim. Sci. 76, 1887-1895.

Canibe, N., Bach Knudsen, K.E., 1997. Digestibility of dried and toasted peas in pigs. 1. Ileal and total tract digestibilities of carbohydrates. Anim. Feed Sci. Technol. 64, 293-310.

Cera, K.R., Mahan, D.C., Reinhart, D.C., 1989. Apparent fat digestibilities and performance responses of postweaning swine fed diets supplemented with coconut oil, corn oil or tallow. J. Anim. Sci. 67, 2040-2047.

Cerisuelo, A., Torres, A., Lainez, M., Moset, V., 2012. Increasing energy and lysine in diets for growing-finishing pigs in hot environmental conditions: Consequences on performance, digestibility, slurry composition and gas emission. J. Anim. Sci. 90, 1489-1498.

CVB, 2004. Veevoedertabel (Livestock Feed Table). Centraal Veevoeder Bureau, Lelystad, The Netherlands.

EEA, 2014a. European Union emission inventory report 1990-2012 under the UNECE Convention on Long-range Transboundary Air Pollution (LRTAP). European Environment Agency. Technical Report 12/2013.

EEA, 2014b. Annual European Union greenhouse gas inventory 1990-2012 and inventory report 2014. Submission to the UNFCCC Secretariat. European Environment Agency. Technical Report 9/2013.

FEDNA, 2006. Necesidades nutricionales para ganado porcino: Normas FEDNA. In: De Blas, C., Gasa, J., Mateos, G.G. (Eds.), Fundación Española para el Desarrollo de la Nutrición Animal. FEDNA, Madrid, Spain, 55 pp.

FEDNA, 2010. Tablas FEDNA de composición y valor nutritivo de alimentos para la fabricación de piensos compuestos. In: De Blas, C., Mateos, G.G., García-Rebollar, P. (Eds.), Fundación Española para el Desarrollo de la Nutrición Animal. , 3rd ed. FEDNA, Madrid, Spain, 502 pp.

Graham, H., Hesselman, K., Aman, P., 1986. The influence of wheat bran and sugar beet pulp on the digestibility of dietary components in a cereal-based pig diet. J. Nutr. 116, 242-251.

Heimendahl, E., Breves, G., Abel, H.J., 2010. Fiber-related digestive process in three different breeds of pigs. J. Anim. Sci. 88, $972-981$.

Hernández, F., Martínez, S., López, C., Megías, M.D., López, M., Madrid, J., 2011. Effect of dietary crude protein levels in a commercial range, on the nitrogen balance, ammonia emission and pollutant characteristics of slurry in fattening pigs. Animal 5, 1290-1298.

INRA, 2002. Valeursnutritives pour les volaillles. In: Sauvant, D., Perez, J.M., Tran, G. (Eds.), Tables de composition et de valeur nutritive des matières premiéres destinées aux animaux d'élevage. INRA Editions, Paris Cedex, France.

Jarret, G., Martinez, J., Dourmad, J.Y., 2011a. Effect of biofuel co-products in pig diets on the excretory patterns of N and C on the subsequent ammonia and methane emissions from pig effluent. Animal. 5, 622-631.

Jarret, G., Cozannet, P., Martinez, J., Dourmad, J.Y., 2011b. Effect of different quality wheat dried distiller's grain solubles (DDGS) in pig diets on composition of excreta and methane production from faeces and slurry. Livest. Sci. 140, 275-282.

Jarret, G., Cerisuelo, A., Peu, P., Martinez, J., Dourmad, J.Y., 2012. Impact of pig diets with different fiber contents on the composition of excreta and their gaseous emissions and anaerobic digestion. Agric. Ecosyst. Environ. 160, 51-58.

Kil, D.Y., Sauber, T.E., Jones, D.B., Stein, H.H., 2010. Effect of the form of dietary fat and the concentration of dietary NDF on ileal and total tract endogenous losses and apparent and true digestibility of fat by growing pigs. J. Anim. Sci. 88, 2959-2967.

Kreuzer, M., Wittmann, M., Gerdemann, M.M., Hanneken, H., Abel, H., Machmuller, A., 1999. Re-examination of the metabolizable energy contents of various rations containing different types and levels of bacterially fermentable substrates in digestibility experiments with growing pigs. J. Anim. Physiol. Anim. Nutr. 82, 33-49.

Leek, A.B.G., Beattie, V.E., O'Doherty, J.V., 2004. The effects of dietary oil inclusion and oil source on apparent digestibility, faecal volatile fatty acid concentration and manure ammonia emission. Anim. Sci. 79, 155-164.

McCrory, D.F., Hobbs, P.J., 2001. Additives to reduce ammonia and odor emissions from livestock wastes. Environ. Qual. $30,345-355$.

Nahm, K.H., 2003. Influences of fermentable carbohydrates on shifting nitrogen excretion and reducing ammonia emission of pigs. Crit. Rev. Environ. Sci. Technol. 30, 135-186.

Portejoie, S., Dourmad, J.Y., Martinez, J., Lebreton, Y., 2004. Effect of lowering dietary crude protein on nitrogen excretion, manure composition and ammonia emission from fattening pigs. Livest. Prod. Sci. 91, 45-55.

Powles, J., Wiseman, J., Cole, D.J.A., Hardy, B., 1993. Effect of chemical structure of fats upon their apparent digestible energy value when given to growing/finishing pigs. Anim. Prod. 87, 137-146.

SAS Institute, 2008. SAS/STAT ${ }^{\circledR}$ User's guide, version 9.3. SAS Institute Inc., Cary, NC.

Torres-Pitarch, V., Moset, V., Ferrer, P., Cambra-López, M., Hernández, P., Coma, J., Pascual, M., Serrano, P., Cerisuelo, A., 2014. The inclusion of rapeseed meal in fattening pig diets, as a partial replacer of soybean meal alters nutrient digestion, faecal composition and biochemical methane potential from faeces. Anim. Feed Sci. Technol. 198, 215-223.

Triolo, J.M., Sommer, S.G., Møller, H.B., Weisbjerg, M.R., Jiang, X.Y., 2011. A new algorithm to characterize biodegradability of biomass during anaerobic digestion: influence of lignin concentration on methane production potential. Biores. Tech. 2011, 9395-9402.

Wiseman, J., Cole, D., 1983. Interaction between dietary free fatty acids and calcium in growing pigs. In: Proceedings of the 5th World Conference on Animal Production, Tokyo, pp. 423-424.

Wiseman, J., Cole, D.J.A., Hardy, B., 1990. The dietary energy values of soya-bean oil, tallow and their blends for growing/finishing pigs. Anim. Prod. 50, 513-518. 